\title{
Detection of Pathogenic Leptospiral DNA Traces in Canine Sera Serum Samples by Loop Mediated Isothermal Amplification (LAMP)
}

\author{
Sylvia Grune Loffler ${ }^{1,2, *}$, Carlos Leiva ${ }^{1,2}$, Exequiel Scialfa ${ }^{3}$, Leandro Redondo ${ }^{1,2}$, \\ Mónica Florin-Christensen ${ }^{1,2}$, Mara Martínez ${ }^{1}$, Graciela Romero ${ }^{1}$, Bibiana Brihuega ${ }^{1}$ \\ ${ }^{1}$ Institute of Pathobiology, Laboratory of Leptospirosis, National Institute of Agricultural Technology, Argentina \\ ${ }^{2}$ National Research Council of Argentina (CONICET), Buenos Aires, Argentina \\ ${ }^{3}$ Division of Rural Zoonosis, Azul, Buenos Aires province, Argentina
}

Copyright $\bigcirc 2016$ by authors, all rights reserved. Authors agree that this article remains permanently open access under the terms of the Creative Commons Attribution License 4.0 International License

\begin{abstract}
Leptospirosis is a worldwide distributed zoonosis, caused by pathogenic strains of spirochetes belonging to the genus Leptospira spp. So far, the only gold standard diagnostic method for this disease has been the Micro-Agglutination Test (MAT). The purpose of this study was to test whether a correlation exists between serological diagnosis by MAT and the presence of Leptospira spp. DNA traces in serum. Anti-Leptospira spp. antibody titers were determined in dog serum samples obtained at a canine shelter from Buenos Aires Province, Argentina $(\mathrm{n}=80)$ by MAT using ten Leptospira spp. serovars. DNA extracted from these samples using Chelex-100 resin was used as template for Leptospira spp. specific PCR and loop-mediated isothermal amplification (LAMP) tests. In the latter case, product detection by incubation with malachite green dye was set up, obtaining optimal results at a dye concentration of $0.02 \%(\mathrm{w}(\mathrm{v}))$ and a $\mathrm{pH}$ of 6.1 . PCR and LAMP showed the same sensitivity, detecting leptospiral DNA in 12 out of the 48 MAT- positive sera. No detection was attained by either method in MAT-negative samples. These results show that it is possible to use LAMP for the detection of leptospirosis in non-human mammals. It also shows that, in the case of serum samples, MAT has higher diagnostic sensitivity than the currently available PCR and LAMP tests.
\end{abstract}

Keywords Leptospirosis, Serum, LAMP, Diagnostics, Canine

\section{Introduction}

Pathogenic strains of Leptospira spp. belong to the order Spirochaetales, family Leptospiraceae and are the causative bacterial agent of leptospirosis. This disease is the most widespread zoonosis in the world, being endemic in most tropical and subtropical regions. It is often misdiagnosed in humans suffering from other febrile diseases, like meningitis and dengue. Yearly, an estimate of 500.000 cases is diagnosed worldwide, and the mortality rate is over $10 \%$ [1]. During the 11 first epidemiological weeks of 2016, 1442 human cases were officially reported in Argentina [2].

Domestic and wild animals can also be infected with pathogenic Leptospira spp. [3]. In the case of dogs, clinical signs and severity of the disease vary depending on the geographic population, infecting serovar and host immune response [4] .Clinical signs indicative of a leptospiral infection in dogs include renal or hepatic failure, uveitis, pulmonary hemorrhage, acute febrile illness or abortion $[4,5,6]$. In addition, leptospira infections of dogs are of public health concern. Indeed, a Leptospira spp. infection of a veterinarian during examination of a pet rat for fleas was recently reported [9], and similar situations could take place during routine examination of dogs. This risk highlights the importance of following infection control guidelines and improving our understanding of the epidemiology of leptospirosis in dogs.

In Buenos Aires Province, serological studies using the Micro-Agglutination Test (MAT) found seroreactivity against the following serovars in dogs: Bataviae, Canicola, Castellonis, Icterohaemorrhagiae, Grippotyphosa, Pyrogenes, Pomona, Tarassovi [5,6] and also Cynopteri[7].

Pathogenic Leptospira spp. strains isolated so far from dogs in Argentina have been serotyped by Cross Agglutination Absorption test (CAAT) belong to the $L$. interrogans species and the Canicola, Icterohaemorrhagiae and Pyrogenes serogroups [8]. Accordingly, Grune et al. [10] found $L$. interrogans as the only species infecting dogs, and distinguished four different serovars, Canicola Hond Utrecht IV, Portlandvere MY 1039, Icterohaemorrhagiae RGA, and Pomona Baires, by Multiple Locus Variable number tandem repeats Analysis (MLVA). 
In addition to serological methods, rapid, specific and sensitive nucleic acid amplification assays, such as PCR, are available for most bacterial pathogen diagnosis. However, an expensive thermal cycler is an indispensable requirement for PCR assays which limits its wide application. Loop-mediated isothermal amplification (LAMP) constitutes an attractive alternative to PCR since it amplifies a specific fragment of DNA in less than an hour, under isothermal conditions, which can be achieved in a water bath or heat block [11]. Detection can be achieved by analyzing products by gel electrophoresis or directly by the naked eye after addition of DNA specific dyes.

LAMP technology has been used and tested for the detection pathogenic viruses, bacteria, fungi, rickettsia, protozoan and tapeworms [17]. Most of these pathogens affect humans. For canines, LAMP was applied to the detection of Anaplasma phagocytophilum, Babesia canis canis, Echinococcus granulosus, canine parvovirus and canine distemper virus [17]. This technology has also been tested for the detection of Leptospira spp. in human urine and blood samples [18, 19,20,21], but no studies have so far used LAMP to detect pathogenic Leptospira spp. in animal samples.

In this study, we tested whether it was possible to detect traces of pathogenic leptospiral DNA in canine serum samples by PCR and LAMP, and analyzed the diagnostic potential of these methods as compared to MAT.

\section{Materials and Methods}

\subsection{Samples Used in this Study}

Blood (5 ml) without anticoagulant was collected from the jugular vein of 80 canines from a shelter located in the province of Buenos Aires and serum was separated by centrifugation. DNA was extracted from $20 \mu \mathrm{l}$ of each undiluted canine serum sample using Chelex-100 resin (Bio Rad) according to Grune et al. [23]. Serum and DNA samples were stored at $-20^{\circ} \mathrm{C}$ until use.

\subsection{Microscopic Agglutination Test (MAT)}

For serological diagnosis of canine samples $(n=80)$, a Micro-Agglutination Test was performed at $28-30^{\circ} \mathrm{C}$ using a battery of live strains of Leptospira interrogans serovars (Canicola, Hardjo, Hebdomadis, Icterohaemorrhagiae, Pomona, Pyrogenes, Wolffi, Tarassovi), L. borgeptersenii serovar Castellonis belonging to the serogroup Ballum and $L$. kirschneri serovar Grippothyphosa. Equal volumes of antigen and serum dilutions were mixed in glass tubes, and allowed to react during 1.5 to $4 \mathrm{~h}$ at room temperature, as described in Faine et al. [22]. Then, the presence or absence of a precipitate was evaluated under dark-field microscopy to determine end point titers.

\subsection{PCR}

A duplex PCR using primers G1-G2 (G1: CTGAATCGCTGTATAAAAGT;

G2:GCAAAACAAATGGTCGGAAG) and B64I-B64II (B64I: CTGAATTCTCATCTCAACTC and B64II: GCAGAAATCAGATGGACGAT), modified from Gravekamp et al. [24] was used in this study. Reactions were carried out in a final volume of $50 \mu \mathrm{l}$, which contained $2 \mu \mathrm{l}$ purified DNA template. PCR mixture contained 10X buffer (500mM-KCL, 20mM MgCl2, 100mM-Tris/HCL, pH 9.0), $0.5 \mu \mathrm{l}$ of $50 \mu \mathrm{mol}$ for each primer, $0.5 \mathrm{ml}$ dNTP solution $(10 \mathrm{mM})$ (Invitrogen, Carlsbad, CA, USA) and Taq polymerase (0.5 U) (Embiotech, Buenos Aires, Argentina). The cycling program consisted of $5 \mathrm{~min}$ at $94^{\circ} \mathrm{C}$, followed by 34 cycles of $94^{\circ} \mathrm{C}(1.5$ minutes $), 55^{\circ} \mathrm{C}$ ( 1 minute) and $72^{\circ} \mathrm{C}$ ( 2 minutes), with a final extension period of $7 \mathrm{~min}$ at $72^{\circ} \mathrm{C}$. PCR was carried out in a My Cycler TM thermocycler (Bio Rad). Amplification products were analyzed by electrophoresis in ethidium bromide stained $2 \%$ agarose gels, followed by exposure to UV light (Uvi Tec transiluminator BTS-20.M). Amplicon sizes were estimated using a $100 \mathrm{bp}$ ladder (Embiotech, Buenos Aires, Argentina).

\subsection{LAMP}

LAMP reaction was carried out with six primers targeting the rRNA 16S (Lepto-rrs) gene (GenBank Accession Number NC_004342), as described previously by Koizumi et al. (2012). The LAMP reaction mix $(25 \mu \mathrm{l})$ consisted of $1 \mathrm{X}$ Isothermal Amplification buffer $(20 \mathrm{mM}$ Tris- $\mathrm{HCl}, 10$ $\mathrm{mM}\left(\mathrm{NH}_{4}\right)_{2} \mathrm{SO}_{4}, 50 \mathrm{mM} \mathrm{KCl}, 2 \mathrm{mM} \mathrm{MgSO} 4,0.1 \%$ Tween-20, pH 8.8) (New England BioLabs, Ipswich, MA, USA), $1.4 \mathrm{mM}$ each dNTP (Invitrogen, Carlsbad, CA, USA), $1.5 \mu \mathrm{M}$ FIP/BIP, $0.5 \mu \mathrm{M} \mathrm{F} 3 / \mathrm{B} 3,1.5 \mu \mathrm{M} \mathrm{LF} / \mathrm{LB}, 12 \mathrm{mM}$ $\mathrm{MgSO}_{4}, 1 \mathrm{M}$ betaine (Sigma-Aldrich, MO, USA), $8 \mathrm{U}$ of $B s t$ 2.0 WarmStar DNA polymerase (New England BioLabs) and $2 \mu \mathrm{l}$ of DNA template. The reaction was incubated at $63^{\circ} \mathrm{C}$ for $60 \mathrm{~min}$ (this optimal reaction temperature was experimentally determined) and subsequently at $95^{\circ} \mathrm{C}$ for 5 min to terminate the reaction in a heat block. Positive, negative and blank controls were included in each LAMP assay. In order to confirm the amplification of leptospiral DNA, the product obtained was detected by visual inspection as well as by electrophoresis in $2 \%$ agarose gels followed by staining with ethidium bromide and visualization under UV light. The sensitivity of this LAMP assay was tested using dilutions of positive serum samples (Figure 1). Genomic DNA from Leptospira biflexa (saprophyte) and other Bacteria, including Brucella abortus 2308, Clostridium perfringens 130, Klebsiella pneumonae ATCC 700603, E. coli 12/538 and Mycobacterium bovis AN5 were also used and results were negative in all cases. 


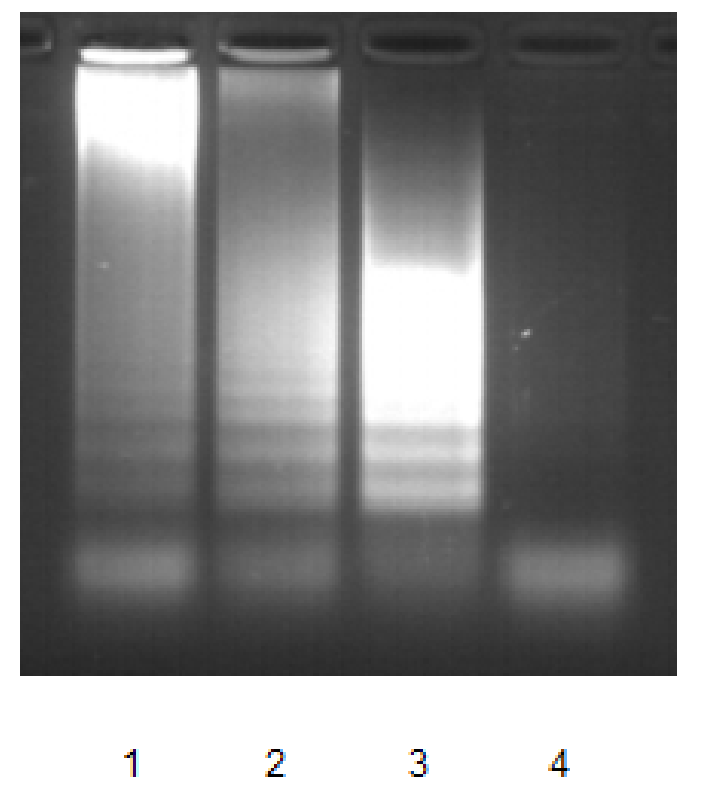

Figure 1. Gel electrophoresis ( $2 \%$ ) of LAMP reactions using dilutions of a positive canine serum sample. Line 1: 1/10, line 2: 1/50, line 3:positive control ,Line 4: negative control.

\subsection{End point detection of LAMP products:}

Malachite green solution was prepared as a $1 \%(\mathrm{w} / \mathrm{v})$ stock solution in $\mathrm{ddH}_{2} \mathrm{O}$, and further diluted with $\mathrm{ddH}_{2} \mathrm{O}$ to obtain a $0.02 \%$ working solution, which was stored at $4{ }^{\circ} \mathrm{C}$ for 30 days. In order to optimize color change, , different $\mathrm{pH}$ values of the working solution $(4.2,4.9,6.1,7.1,8.1$ and 9.2) were tested. Five $\mu \mathrm{l}$ of these solutions were added to the tubes before amplification. LAMP results were observed directly and under UV light (Figure 2). In the upper part of the Figure 2, LAMP reactions in tubes can be observed under visible light (A), in the middle part of the figure (B) the same tubes were exposed under UV light for ( $\sim 10$ seconds $)$ and in the lower part of the figure (C) can be the tubes observed under UV light.

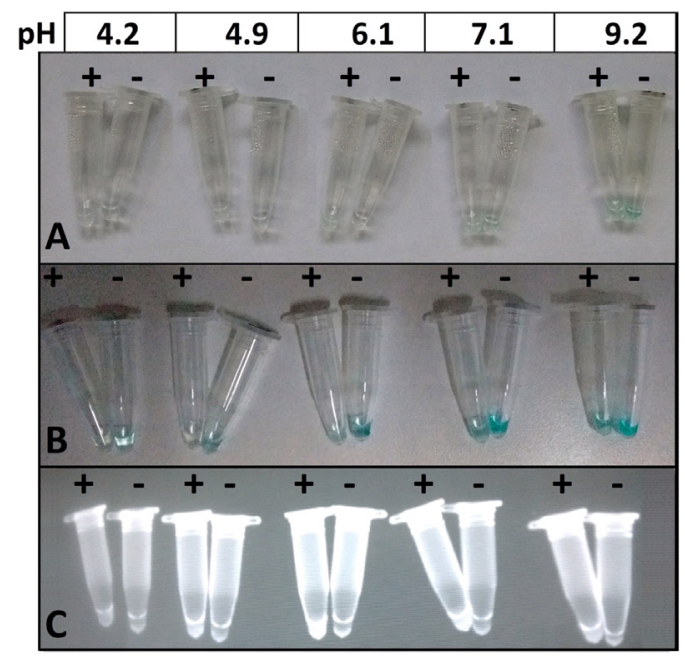

Figure 2. Visual detection of LAMP products after addition of malachite green. (A) visible light. (B) visible light after a short UV light exposure. (C) UV light. Positive reactions have turbidity and are bright and clearer than negative reactions, which stay green.

\section{Results}

From the 80 canine serum samples analyzed, 48 were positive by MAT. Of these, 12 were positive by PCR and LAMP (Table 1). Details on the positive 12 samples are indicated in Table 2. MAT-positive serum samples that yielded negative results by PCR and LAMP $(n=36)$ had low titers $(\leq 1 / 200)$ to serovar Castellonis and serovar Canicola. All MAT-negative samples $(\mathrm{n}=32)$ were neither positive to PCR nor to LAMP (Table 3).

Table 1. Leptospira spp. detection in canine serum samples from Buenos Aires, Argentina, by PCR, LAMP and MAT $(\mathrm{n}=80)$

\begin{tabular}{|c|c|c|}
\hline Canine serum samples & PCR/LAMP & MAT \\
\hline 12 & + & + \\
\hline 36 & - & + \\
\hline 32 & - & - \\
\hline Total $=80$ & & \\
\hline
\end{tabular}

Table 2. Antibody titers by MAT of serum samples in which leptospiral DNA could be detected by PCR and LAMP $(n=12)$

\begin{tabular}{|c|c|c|}
\hline Serovar & Titer & $\mathbf{n}$ \\
\hline Pomona/Canicola & $\begin{array}{c}1: 3200 / 1: 12800 \\
1: 1600 / 1: 3200\end{array}$ & 1 \\
\hline Ictero/Pomona/Canicola & $1: 600 / 1: 12800 / 1: 12800$ & 1 \\
\hline Castellonis/Canicola/ & $\begin{array}{c}1: 200 / 1: 100 / 1: 100 \\
1: 200 / 1: 100 / 1: 200 \\
\text { Grippothyphosa }\end{array}$ & 1 \\
\hline Castellonis/Canicola/ & $1: 100 / 1: 100 / 1: 1600$ & 1 \\
\hline $\begin{array}{c}\text { Grippothyphosa/Hardjo/ } \\
\text { Hebdomadis }\end{array}$ & $1: 200 / 1: 200 / 1: 200 / 1: 100 / 1: 100$ & 1 \\
\hline Castellonis/Canicola/ & $1: 200 / 1: 100 / 1: 100 / 1: 100$ & 1 \\
\hline Grippothyphosa/Hardjo & $1: 100 / 1: 100$ & 1 \\
\hline Castellonis/Grippothyphosa & $1: 100 / 1: 100$ & 1 \\
\hline Castellonis/Canicola & $1: 100 / 1: 100 / 1: 100 / 1: 100$ & 1 \\
\hline Castellonis/Canicola/ & & 12 \\
\hline Grippothyphosa/Hebdomadis & &
\end{tabular}

Table 3. Antibody titers by MAT of serum samples that resulted negative to leptospiral DNA detection by MAT, PCR and LAMP $(n=32)$

\begin{tabular}{|c|c|c|}
\hline Serovar & Titer & n \\
\hline Icterohaemorrhagiae & $1: 200$ & 3 \\
\hline Castellonis & $1: 200$ & 6 \\
\hline Canicola/ Icterohaemorrhagiae & $1: 200 / 1: 100$ & 8 \\
\hline $\begin{array}{c}\text { Castellonis/ Canicola/ } \\
\text { Grippothyphosa }\end{array}$ & $1: 100 / 1: 100 / 1: 100$ & 2 \\
\hline Castellonis/Canicola/ & $1: 100 / 1: 100 / 1: 100$ & 4 \\
\hline Icterohaemorrhagiae & $1: 100 / 1: 200 / 1: 100$ & 3 \\
\hline Castellonis/ Canicola/ Pomona & & 32 \\
\hline Total & & 6 \\
\hline
\end{tabular}

To check the sensitivity of LAMP reaction, DNA from a positive serum sample by MAT, PCR and LAMP was diluted $1 / 10$ and $1 / 50$, and used as template for the reaction. LAMP reaction was observed in all cases in ethidium bromide stained gels after electrophoresis. DNA from saprophyte Leptospira spp. or other Bacteria did not amplify using LAMP assay (results not shown). To observe LAMP 
positive results without the need of gel electrophoresis, malachite green in a final concentration of $0.02 \%$, adjusted to various $\mathrm{pH}$ values was added to the reaction mixture before amplification. Once the reaction was finished, no color changes were observed under visible light, with only a slight color difference between a positive and negative tube at $\mathrm{pH}$ 9.2. Surprisingly, after exposure to UV light ( $10 \mathrm{~s})$, followed by observation under visible light, tubes with malachite green solution adjusted to $\mathrm{pH} 6.1,7.1$ and 9.2 showed a color change from green to light blue. Malachite Green solutions at $\mathrm{pH} 8$ or 10 were not used due to the fact that in these conditions, the solution is almost transparent, and thus, color changes cannot be detected. The best discrimination between positive and negative reactions was achieved at pH 6.1 (Figure 2B). Almost no color differences between positive and negative reactions were observed in tubes containing acidic malachite green solution $(\mathrm{pH} 4.2$ and 4.9). Observation under UV light showed that positive reactions were associated with turbidity while negative reactions were clear (Figure 2C). In order to confirm LAMP results, characteristic ladder patterns as that shown in Figure 1 were only observed in positive reactions (results not shown). Cresol red/orange addition to the tube after amplification did not discriminate between positive and negative reactions (data not shown).

\section{Discussion}

The Microscopic Agglutination Test (MAT) is the gold standard of serological diagnosis of leptospirosis in animals and human $[3,22]$. However, it requires considerable time and dedication of a specialized technician to detect agglutination of antibodies. It does not detect early leptospirosis, when the clinical symptoms are pronounced. This is a critical constraint since an early diagnosis is crucial to initiate treatment. In the past decade, a number of efficient PCR assays have been developed for the detection of Leptospira spp. from clinical samples. However, not every laboratory in endemic countries has the necessary equipment to molecularly diagnose leptospirosis by PCR. LAMP, on the other hand, constitutes a low cost technique, which at the same time is sensitive and effective in the detection of pathogenic strains of Leptospira spp.

One of the advantages of LAMP method is the simple and effective detection of nucleic acids. Addition of malachite green to the tubes followed by UV exposure allowed discriminating between positive and negative results. The detection method used in this work can be coupled to a closed tube system as low malachite green concentration is not associated with the inhibition of the LAMP assay[12 A closed tube system lowers the risk of amplicon contamination of working areas and other materials (i.e. pipettes, gloves, plastic ware) as compared to protocols where tubes need to be opened to add dyes or loading buffer $[25,26]$ The conditions of malachite green addition were adjusted and it was observed that optimal conditions were a final concentration of $0.02 \%$, and a $\mathrm{pH}$ value of 6.1 . After UV light exposure the positive reaction tube containing malachite green turned light blue under these conditions and the negative turned green. In a recent study [27], malachite green was also used for end point detection of LAMP reactions for Plasmodium spp. parasites.

The optimal concentration in this study was $0.004 \%$, but color changes were different than those observed in other reports $[12,27,28]$. This difference in color changing could be attributed to the fact that each LAMP reaction has specific reaction conditions (i.e., presence/absence of betaine or $\mathrm{SO}_{4} \mathrm{Mg}_{2}, \mathrm{pH}$ conditions). Importantly, discrimination of LAMP results was feasible by the naked eye.

In this study, a rrs LAMP assay for the detection of pathogenic leptospiral DNA traces in canine serum samples was tested with positive results. LAMP guarantees high performance at a low cost and it has the potential to be used in the veterinary field, since it does not require special equipment and could be used in the field in a version of a portable kit. However, more assays have to be done to evaluate LAMP as an alternative for leptospirosis diagnosis.

\section{Sponsorship}

This study was financed by Proyecto Nacional de Sanidad Animal (PNSA) INTA, AESA 202821.

\section{REFERENCES}

[1] World Health Organization (WHO). Report of the first meeting of the leptospirosis burden epidemiology reference group. WHO Press, Geneva, Suiza. 2010; 40pp.

[2] National Health Ministry (Ministerio de Salud). Presidencia de la Nación. Boletín Integrado de Vigilancia 2016; № 306-SE 16-Abril: 104pp.

[3] Levett PN. Leptospirosis. Clin Microbiol Rev.2001. 14:296-326.

[4] Klaasen H, Van der Veen M, Molkenboer M, Sutton D. Novel tetravalent Leptospira bacterin protects against infection and shedding following challenge in dogs. Veterinary Record. 2012; 172:181. doi:10.1136/vr.101100

[5] Brihuega B. \& Martiarena B. Incidencia de la leptospirosis en caninos de la ciudad de Buenos Aires y Gran Buenos Aires. Rev Vet Arg. 1994; 102:98.

[6] Carugati A. Leptospirosis en caninos: epidemiología, patogenia y diagnóstico clínico. In: Cacchione R, Durlach R, Larghi O, editors. Temas de Zoonosis II, 1st ed. Buenos Aires, Asociación Argentina de Zoonosis, 2004, p. 182-91.

[7] Tealdo MS, Romero GN, Autrey CD, Samartino L. Serología positiva a Leptospira interrogans serovar Cynopteri en caninos de la Ciudad de Buenos Aires, Argentina. In Vet. 2007; 9:59-65. 
[8] Cacchione R, Cascelli E, Saravi M, Martínez E. Difusión e importancia de la leptospirosis animal y humana en la Argentina. MedVet. 1980; 61:236-46.

[9] Bear R, Turnberg W, Yu D, Whorle R. Leptospirosis in a small animal veterinarian: reminder to follow standardized infection control procedures. Zoonoses Public Health. 2010; 57:281-4.

[10] Grune Loffler S, Passaro D, Samartino L, Soncini A, Romero G, Brihuega B. Genotypes of Leptospira spp. strains isolated from dogs in Buenos Aires, Argentina. Rev. Argent. Microbiol. 2014; 46(3): 1-13.

[11] Notomi T, Okayama H, Masbuchi H, Yonekawa T, Watanabe $\mathrm{K}$, Amino N, Hase T. Loop-mediated isothermal amplification of DNA. Nucleic Acids Res. 2000; 28: E63.

[12] Nzelu C, Gomez E, Cáceres A, Sakurai T, Martini-Robles L, Uezato H, Mimori T, Katakura K, Hashiguchi Y, Kato H. Development of a loop-mediated isothermal amplification method for rapid mass-screening of sand flies for Leishmania infection. Acta Tropica.2014; 132: 1-6.

[13] Jothikumar P, Narayanan J, Hill V. Visual endpoint detection of Escherichia coli O157:H7 using isothermal Genome Exponential Amplification (GEAR) assay and malachite green. Journal of Microbiological Methods. 2014; 98: 122-127.

[14] Tanner N, Zhang Y, Evans T. Visual detection of isothermal nucleic acids amplification using $\mathrm{pH}$-sensitive dyes. BioTechniques. 2015; 58: 59-68.

[15] WHO Expert Meeting Report. The use of a commercial loop-mediated isothermal amplification assay (TB-lamp) for the detection of tuberculosis, WHO/HTM/TB/2013.05. World Health Organization, Geneva. 2013; 37 pp.

[16] Fischbach J, Xander N, Frohme M, Glökler J. Shining a light on LAMP assays- A comparison of LAMP visualization methods including the novel use of berberine. BioTechniques. 2015; 58: 189-194.

[17] Abdullahi U, Naim R, Taib W, Saleh A, Mauzu A, Aliyu S, Baig A. Loop-Mediated Isothermal Amplification (LAMP), An Innovation in Gene Amplification: Bridging the Gap in Molecular Diagnostics; A Review. Indian Journal of Science and Technology, Vol 8(17). DOI: 10.17485/ijst/2015/v8i17/ 55767

[18] Suwancharoen D, Kulchim C, Chirathaworn C, Yoshida S. Development of a novel primer combination to detect pathogenic Leptospira by loop-mediatedisothermal amplification. J Microbiol Methods. 2012; 91(1):171-3. doi: 10.1016/j.mimet.2012.08.008.

[19] Koizumi N, Nakajima C, Harunari T, Tanikawa T, Tokiwa T,
Uchimura E, Furuya T, Mingala CN, Villanueva MA, Ohnishi M, Suzuki Y. A new loop-mediated isothermal amplification method for rapid, simple, and sensitive detection of Leptospira spp. in urine. J Clin Microbiol. 2012; 50(6):2072-4. doi: 10.1128/JCM.00481-12.

[20] Sonthayanon P, Chierakul W, Wuthiekanun V, Thaipadungpanit J, Kalambaheti T, Boonsilp S, Amornchai P, Smythe LD, Limmathurotsakul D, Day NP, Peacock SJ.Accuracy of loop-mediated isothermal amplification for diagnosis of human leptospirosis in Thailand. Am J Trop Med Hyg. 2011; 84(4):614-20. doi: 10.4269/ajtmh.2011.10-0473.

[21] Lin X, Chen Y, Lu Y, Yan J, Yan J. Application of a loop-mediated isothermal amplification method for the detection of pathogenic Leptospira. Diagn Microbiol Infect Dis. 2009; 63(3):237-42. doi: 10.1016/j.diagmicrobio.2008.1 0.012 .

[22] Faine S, Adler B, Balin C, Perolat P. Leptospira and Leptospirosis. 1999; MedSCi, Melbourne, Australia. 272pp.

[23] Grune S. Aislamiento y caracterización genotípica de leptospiras provenientes de animales silvestres en tres ecoregiones argentinas mediante la técnica del Múltiple-Locus Variable-number tandem repeat Análisis (MLVA): Coincidencia con genotipos provenientes de animales de producción. 2014. [PhD Thesis]. Universidad de Buenos Aires, Facultad de Ciencias Veterinarias; Buenos Aires, Argentina. 135pp

[24] Gravekamp C, Van de Kemp H, Franzen M, Carrington D, Schoone GJ, Van Eys GJ, et al. Detection of seven species of pathogenic leptospires by PCR using two sets of primers. J. Gen. Microbiol. 1993; 139(8); 1691-700.

[25] Lau Y, Meganathan P, Sonaimuthu P, Thiruvengadam G, Nissapatorn V, Chen Y. Specific, sensitive, and rapid diagnosis of active toxoplasmosis by a loop-mediated isothermal amplification method using blood samples from patients. Journal of Clinical Microbiology. 2010; 48(10): 3698-3702.

[26] Karthik K, Rathore R, Thomas P, Arun TR, Viswas KN, Dhama K, Agarwal RK. New closed tube loop mediated isothermal amplification assay for prevention of product cross contamination. 2014. MethodsX.1 137-43.

[27] Lucchi NW, Ljolje D, Silva-Flannery L, Udhayakumar V. Use of Malachite Green- Loop Mediated Isothermal Amplification for Detection of Plasmodium spp. Parasites. PLos ONE. 2016; 11(3): e0151437.doi:10.1371/journal.pone .0151437

[28] Chen HW, Weissenberg G, Atkins E, Chao C, Suputtamongkol Y, Ching W. Highly sensitive Loop-Mediated Isothermal Amplification for the detection of Leptospira. International Journal of Bacteriology 2015; doi:10.1155/2015/147173. 